\title{
Evaluation of Lacrimal Gland Dimensions with MR Imaging in a Turkish Population Sample
}

\author{
Evaluación de las Dimensiones de la Glándula Lagrimal con \\ Imágenes de RM en una Muestra de Población Turca
}

\section{Ozgun Melike Gedar Totuk ${ }^{1}$; Aybike Buse Kalkay²; Kerem Kabadayi²; Mustafa Kemal Demir ${ }^{2}$ \& Cagatay Barut ${ }^{4}$}

GEDAR TOTUK, O. M.; KALKAY, A. B.; KABADAYI, K.; DEMIR. M. K. \& BARUT, C. Evaluation of lacrimal gland dimensions with MR imaging in a Turkish population sample. Int. J. Morphol., 36(4):1431-1438, 2018.

SUMMARY: We aimed to evaluate the morphology of normal lacrimal gland in three different axes in a Turkish population sample by using magnetic resonance (MR) images in relation to sex, age, and side. Cranial MR images obtained by 3 Tesla MR unit of 85 individuals (40 female, 45 male; mean age $42.20 \pm 23.30$ years; age range 2-83 years) performed in Göztepe Medical Park Hospital between December 2015 and July 2017 for non-orbital diseases were evaluated retrospectively. Anteroposterior, craniocaudal, and transverse dimensions of the lacrimal gland were measured on axial, coronal, and sagittal planes of MR images, and were evaluated in relation to side, age, and sex. Axial transverse and sagittal craniocaudal dimensions of lacrimal gland were significantly greater in the right side, as the coronal craniocaudal and sagittal anteroposterior dimensions were greater in the left side. Female and male individuals showed differences in terms of right-left sides in most of the parameters. In Spearman's correlation analysis, age of individuals was negatively correlated with left axial anteroposterior $(r=-0.347, p=0.020)$, left axial transverse $(r=-0.439$, $p=0.003)$, left coronal transverse $(\mathrm{r}=-0.429, \mathrm{p}=0.003)$, and right coronal transverse $(\mathrm{r}=-0.436, \mathrm{p}=0.003)$ dimensions of lacrimal gland. This is the first study determining certain morphometric parameters of the lacrimal gland in Turkish population sample. The side of lacrimal gland, and sex and age of individuals affect its dimensions. On the basis of reference measurements in the present study, orbital MR imaging can be used for the evaluation of lacrimal gland and its pathologies.

KEY WORDS: Head and neck imaging; MRI; Lacrimal gland dimensions; Orbital measurement.

\section{INTRODUCTION}

The lacrimal gland is located in the anterosuperior temporal region of the orbit, between the superior rectus and lateral rectus muscles. It has two continuous lobes, the anterior palpebral and deeper orbital lobes (Duke-Elder \& Wybar, 1961; Obata, 2006). Lacrimal gland lesions constitute approximately $10 \%$ of all orbital pathologies (Kemper \& Schwerdtfeger, 2009). The lacrimal gland diseases include Sjögren's syndrome, idiopathic inflammation, granulomatosis, sarcoidosis, and both benign and malignant neoplasms. These diseases can cause the enlargement or atrophy of the gland, resulting in a significant change in its size (Shields et al., 1989). Because lacrimal gland pathologies are usually atypical and difficult to identify, a precise imaging evaluation has critical importance for the early diagnosis and timely management of these pathologies (Jung et al., 2007).
Computed tomography (CT) has been used traditionally for measuring the lacrimal gland dimensions in the coronal and axial planes, and it is used to assess changes in the size of the gland during the disease process (Tamboli et al., 2011; Harris et al., 2012). However, magnetic resonance (MR) imaging provides high-quality images of the head and neck soft tissue; therefore, it can also be used for the diagnosis and follow-up of lacrimal gland pathologies. When compared to CT, MR imaging has the advantages of improved soft tissue contrast and superior resolution, providing a better evaluation of the orbital structures and glandular tissues (Gündüz et al., 2003; Gao et al., 2013).

It is necessary to obtain a morphological description of the healthy orbits of a population for an effective assessment of diseased orbits. However, the nonpathological

${ }^{1}$ Assistant Professor, Bahcesehir University Faculty of Medicine, Department of Ophthalmology, Istanbul, Turkey.

${ }^{2}$ Medical Student, Bahcesehir University Faculty of Medicine, Istanbul, Turkey.

${ }^{3}$ Professor, Bahcesehir University Faculty of Medicine, Department of Radiology, Istanbul, Turkey.

${ }^{4}$ Professor, Bahcesehir University Faculty of Medicine, Department of Anatomy, Istanbul, Turkey. 
lacrimal gland dimensions in the Turkish population have not yet been reported. Therefore, in this study, we aimed to measure the nonpathological lacrimal gland dimensions via MR imaging in the axial, coronal, and sagittal planes in a Turkish population sample to obtain a morphological description of normal lacrimal glands. We also aimed to evaluate the effects of the side, age, and gender on the lacrimal gland dimensions.

\section{MATERIAL AND METHOD}

Study design and population. The cranial MR images of 85 individuals (40 females and 45 males, mean age $42.20 \pm 23.30$ years old, age range 2-83 years old) obtained at the Goztepe Medical Park Hospital in Istanbul, Turkey between December 2015 and July 2017 were evaluated retrospectively. The MR imaging had been performed to assess the head and neck region. Those individuals with any orbital pathologies, trauma histories, and infiltrating or inflammatory orbital lesions (even if the lesion was unilateral) were excluded from this research.

This study was approved by the Institutional Ethics Committee of Bahcesehir University (December 12, 2017, 2017-19/05), and it was conducted in accordance with the latest version of the Declaration of Helsinki. The participants were given information about the study, and each signed an informed consent form before undergoing any study-related procedure.

MR imaging technique. The cranial MR imaging was performed using a 3 Tesla unit with T1-weighted [repetition time (TR)/echo time (TE): $311 / 2.3 \mathrm{~ms}$ ], diffusion-weighted (DW) (TR/TE: 3708/88 ms; bvalue: $1000 \mathrm{~s} / \mathrm{mm}^{2}$ ), and susceptibility-weighted imaging with a minimum intensity projection (SWI minIP). Contrast-enhanced fat-suppressed three-dimensional turbo field echo sense sequence T1weighted (TR/TE: 7.90/3.50 ms) images were obtained after the intravenous administration of a standard dose of $0.1 \mathrm{mmol} / \mathrm{kg}$ of body weight of gadobutrol (Gadovist@; Bayer Schering Pharma AG, Berlin-Wedding, Germany).

In all the individuals, the MR images were acquired in the axial, sagittal, and coronal planes with 1 -mm contiguous sections over the whole brain. The anteroposterior, craniocaudal, and transverse dimensions of the lacrimal gland were measured in the axial, coronal, and sagittal planes (Fig. 1). Each orbital side of each subject was evaluated separately, and the parameters were evaluated in relation to the side, age, and sex.

Statistical analysis. The study data were summarized using descriptive statistics, including the mean, standard deviation, minimum, and maximum for the continuous variables, and the frequency and percent for the categorical variables. The ShapiroWilk's test was used as a test of normality. For the comparison of the independent groups, an independent samples t test and the MannWhitney $U$ test were used for the normally and non-normally distributed variables, respectively. For the comparison of the dependent groups, a paired samples t test and the Wilcoxon test were used for the normally and non-normally distributed variables, respectively. Spearman's correlation analysis was used for the correlation between the age of subjects and lacrimal gland dimensions.
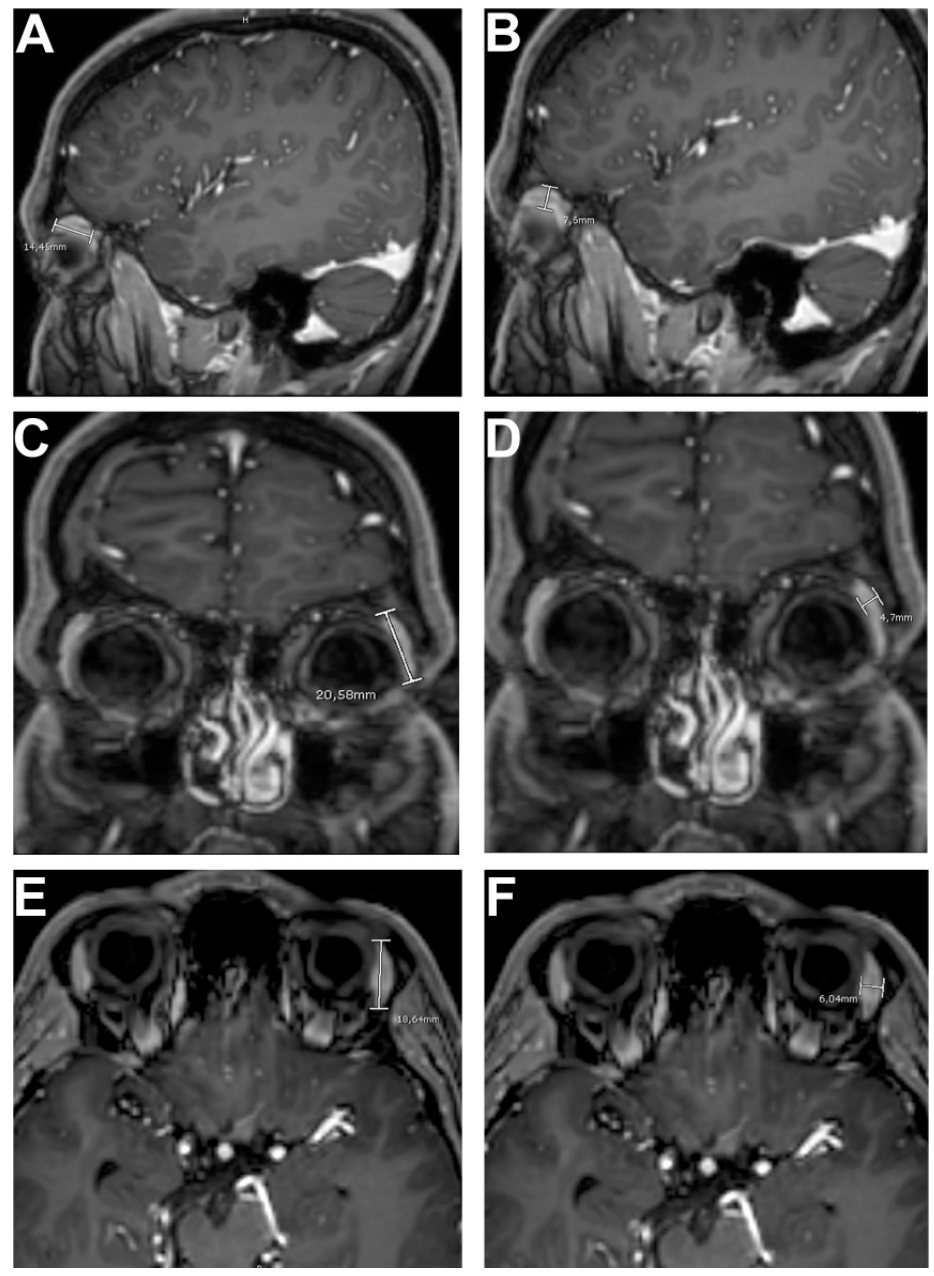

Fig. 1. Anteroposterior (a) and craniocaudal (b) dimensions of the lacrimal gland on sagittal plane; craniocaudal (c) and transverse (d) dimensions of the lacrimal gland on coronal plane; anteroposterior (e) and transverse (f) dimensions of the lacrimal gland on axial plane. 
For the assessment of the intraobserver precision of the measurements, three widely used precision estimates were calculated: the technical error of measurement (TEM), the relative technical error of measurement (rTEM), and the coefficient of reliability (R) (Ulijaszek \& Mascie-Taylor, 1994; Weinberg et al., 2005; Goto \& Mascie Taylor, 2007). The TEM was calculated as the square root of the squared difference between two corresponding measurements divided by twice the sample size (Ulijaszek \& Mascie-Taylor; Goto \& Mascie Taylor; Kemper \& Schwerdtfeger). The TEM was interpreted as the error associated with a certain measurement, and it can be used to estimate the intraobserver precision (Kemper \& Schwerdtfeger). The rTEM was calculated by dividing the TEM for a given variable by the mean for that variable and multiplying the result by 100 (Ulijaszek \& Mascie-Taylor; Goto \& Mascie Taylor; Kemper
\& Schwerdtfeger). The rTEM represents an estimate of the error magnitude as a percentage of the object size (Kemper \& Schwerdtfeger). The $\mathrm{R}$ can be calculated using the TEM, and it ranges from 0 (not reliable) to 1 (complete reliability). It can be calculated using the following equation: $\mathrm{R}=1-$ [(TEM)2/(SD)2], where SD is the standard deviation of all the measurements (Ulijaszek \& Mascie-Taylor; Weinberg et al.; Goto \& Mascie Taylor; Kemper \& Schwerdtfeger). The R represents the between-subject variance free from measurement error (Weinberg et al.).

The Statistical Package for the Social Sciences software (SPSS 19.0; IBM Corporation, Armonk, NY, USA) was used for the statistical analysis, and Excel 2007 was used for all the computations regarding the intraobserver precision. A $\mathrm{p}$ value below 0.05 was assumed to indicate statistical significance.
Table I. Precision estimates of the measurements $(n=30)$

\begin{tabular}{llll}
\hline Lacrimal Gland Dimension $s$ & TEM $(\mathrm{mm})$ & rTEM $(\%)$ & $\mathrm{R}$ \\
\hline Left Axial Ante roposterior $(\mathrm{mm})$ & 0.075 & 0.57 & 0.99 \\
Left Axial Transverse $(\mathrm{mm})$ & 0.083 & 1.56 & 0.99 \\
Left Coronal Craniocaudal $(\mathrm{mm})$ & 0.079 & 0.46 & 0.99 \\
Left Coronal Transverse $(\mathrm{mm})$ & 0.098 & 1.80 & 0.99 \\
Left Sagittal Antero posterior $(\mathrm{mm})$ & 0.113 & 0.90 & 0.99 \\
Left Sagittal Craniocaudal $(\mathrm{mm})$ & 0.107 & 1.05 & 0.99 \\
Right Axial Anteroposterior $(\mathrm{mm})$ & 0.141 & 1.02 & 0.99 \\
Right Axial Transverse $(\mathrm{mm})$ & 0.128 & 2.16 & 0.98 \\
Right Coronal Craniocaudal $(\mathrm{mm})$ & 0.139 & 0.81 & 0.99 \\
Right Coronal Transverse $(\mathrm{mm})$ & 0.121 & 2.24 & 0.98 \\
Right Sagittal Anteroposterior $(\mathrm{mm})$ & 0.105 & 0.85 & 0.99 \\
Right Sagittal Craniocaudal $(\mathrm{mm})$ & 0.125 & 1.06 & 0.99 \\
\hline
\end{tabular}

TEM: technical error of measurement; rTEM: relative technical error of measurement; R: coefficient of reliability.

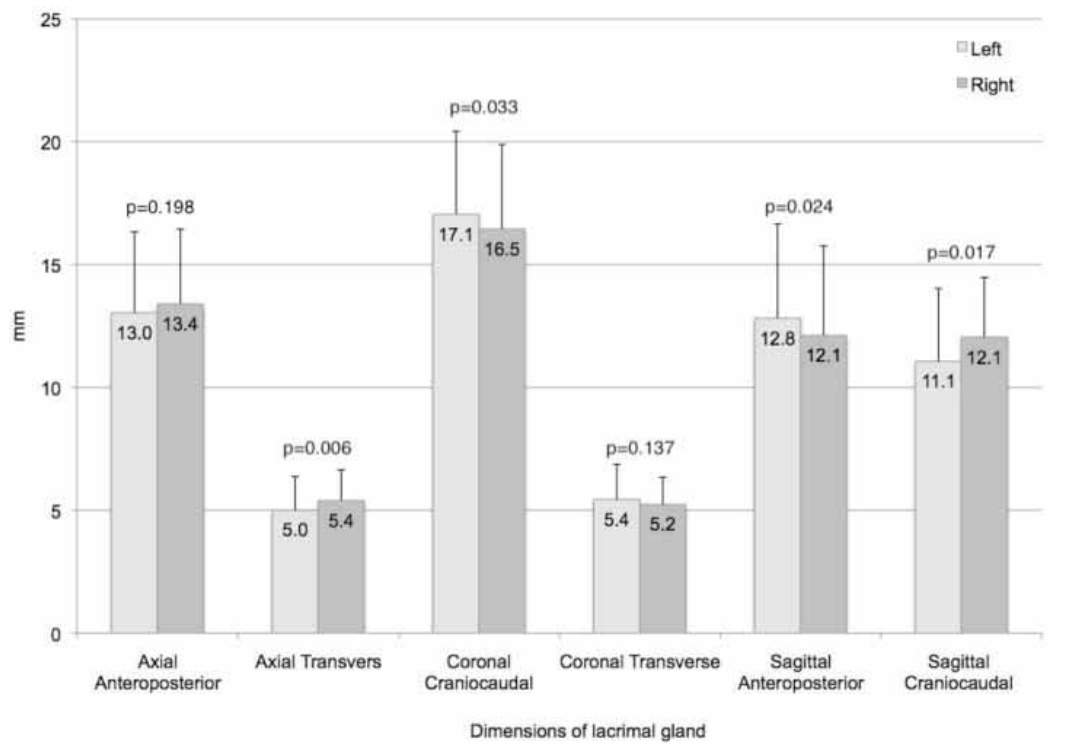

Fig. 2. The mean lacrimal gland dimensions ( \pm standard deviation, $n=85$ ) with respect to side.

\section{RESULTS}

The TEM values of all the variables measured ranged from $0.075-0.141$ $\mathrm{mm}$, and the rTEM values ranged from $0.57-2.24 \%$. The $\mathrm{R}$ values of all the variables were close to 1 , suggesting that most of the variation in the variables in the sample was due to factors other than the measurement error. These results suggest that an acceptable degree of intraobserver precision was obtained for the measurements. The TEM, rTEM, and $R$ values are presented in Table I.

The axial transverse and sagittal craniocaudal dimensions of the lacrimal gland were significantly greater on the right side, while the coronal craniocaudal and sagittal anteroposterior dimensions were greater on the left side (Fig. 2). For the axial anteroposterior and coronal transverse diameters, there were no statistical differences between the right and left sides ( $p>0.05)$ (Fig. 2). Additionally, the female and male individuals showed differences in terms of the right-left sides in most of the parameters (Table II). The axial anteroposterior dimension of the right side and coronal craniocaudal dimension of the left side were significantly higher than those of the contralateral sides in the females, but not the males $(\mathrm{p}<0.05$, 
Table II). However, the axial transverse and sagittal craniocaudal dimensions of the right side were higher than those of the left side in the males, but not the females $(\mathrm{p}<0.05$, Table II).

The left coronal craniocaudal dimension of the lacrimal gland was significantly higher in the females than the males $(17.94 \pm 3.14 \mathrm{~mm}$ and $16.26 \pm 3.40 \mathrm{~mm}$, respectively, $\mathrm{p}=0.022$ ). For the rest of the parameters, there were no statistically significant differences between the sexes (p>0.05) (Table II).

In the Spearman's correlation analysis, the age of individuals was negatively correlated with the left axial anteroposterior $(r=-0.347$, $\mathrm{p}=0.020$ ), left axial transverse $(\mathrm{r}=-0.439, \mathrm{p}=0.003)$, left coronal transverse $(\mathrm{r}=-0.429$, $\mathrm{p}=0.003$ ), and right coronal transverse $\quad(r=-0.436$, $\mathrm{p}=0.003$ ) dimensions of the lacrimal gland (Table III). The right axial anteroposterior and right coronal transverse dimensions were negatively correlated with the age in only the male individuals (Table III). Thus, with advancing age, the values measured for these aforementioned parameters decrease.
Table II. Dimensions of left vs. right lacrimal glands in female vs. male subjects.

\begin{tabular}{|c|c|c|c|}
\hline & Left $(n=85)$ & Right $(\mathrm{n}=85)$ & $\mathrm{p}$ \\
\hline \multicolumn{4}{|c|}{ Axial Anteroposterior (mm) } \\
\hline Female $(n=40)$ & $12.85 \pm 2.87(3.45-17.95)$ & $13.73 \pm 3.03(8.31-18.66)$ & $0.039 a$ \\
\hline Male $(n=45)$ & $13.22 \pm 3.65(3.44-22.12)$ & $13.10 \pm 3.06(5.02-19.58)$ & $0.746 a$ \\
\hline $\mathrm{p}$ value & $0.602^{c}$ & $0.347 \mathrm{c}$ & \\
\hline \multicolumn{4}{|c|}{ Axial Transvers (mm) } \\
\hline Female $(n=40)$ & $5.05 \pm 1.50(2.15-9.06)$ & $5.38 \pm 1.29(2.92-8.32)$ & $0.171 a$ \\
\hline Male $(n=45)$ & $4.95 \pm 1.25(2.23-7.66)$ & $5.40 \pm 1.24(3.00-9.22)$ & $0.007 a$ \\
\hline $\mathrm{p}$ value & $0.747^{\mathrm{c}}$ & $0.966 \mathrm{c}$ & \\
\hline \multicolumn{4}{|c|}{ Coronal Craniocaudal (mm) } \\
\hline Female $(n=40)$ & $17.94 \pm 3.14(11.39-25.02)$ & $16.91 \pm 3.43(10.29-24.17)$ & $0.015 a$ \\
\hline Male $(n=45)$ & $16.26 \pm 3.40(5.56-22.26)$ & $16.03 \pm 3.44(6.17-22.95)$ & $0.552 a$ \\
\hline $\mathrm{p}$ value & $0.022^{\mathrm{c}}$ & $0.244 \mathrm{c}$ & \\
\hline \multicolumn{4}{|c|}{ Coronal Transverse (mm) } \\
\hline Female $(n=40)$ & $5.41 \pm 1.61(2.26-8.64)$ & $5.25 \pm 1.12(3.18-8.21)$ & $0.483 a$ \\
\hline Male $(n=45)$ & $5.47 \pm 1.25(3.08-9.79)$ & $5.24 \pm 1.08(3.17-7.99)$ & $0.170 a$ \\
\hline $\mathrm{p}$ value & $0.909_{d}$ & $0.964 \mathrm{c}$ & \\
\hline \multicolumn{4}{|c|}{ Sagittal Anteroposterior (mm) } \\
\hline Female $(n=40)$ & $13.39 \pm 3.65(6.04-21.37)$ & $12.72 \pm 3.98(4.84-19.57)$ & $0.087 \mathrm{~b}$ \\
\hline Male $(n=45)$ & $12.32 \pm 3.97(4.33-19.91)$ & $11.58 \pm 3.27(5.47-16.75)$ & $0.099 \mathrm{~b}$ \\
\hline $\mathrm{p}$ value & $0.200^{\mathrm{c}}$ & $0.113 \mathrm{~d}$ & \\
\hline \multicolumn{4}{|c|}{ Sagittal Craniocaudal (mm) } \\
\hline Female $(n=40)$ & $10.99 \pm 2.97(3.17-17.33)$ & $11.77 \pm 2.51(5.15-17.77)$ & $0.214 a$ \\
\hline Male $(n=45)$ & $11.12 \pm 3.00(1.98-17.22)$ & $12.37 \pm 2.35(7.12-17.76)$ & $0.024 a$ \\
\hline $\mathrm{p}$ value & $0.831^{\mathrm{c}}$ & $0.391 \mathrm{c}$ & \\
\hline
\end{tabular}
aPaired samples $t$ test, bWilcoxon signed ranks, cIndependent samples $t$ test, dMann-Whitney U test. Data are given as mean \pm standard deviation (min-max).

Table III. Correlation between age of subjects and dimensions of lacrimal gland.

\begin{tabular}{lllll}
\hline Lacrimal Gland & Fimensions & $\begin{array}{c}\text { Female } \\
(\mathrm{n}=40)\end{array}$ & $\begin{array}{c}\text { Male } \\
(\mathrm{n}=45)\end{array}$ & $\begin{array}{c}\text { Total } \\
(\mathrm{n}=85)\end{array}$ \\
\hline Left Axial Anteroposterior & $\mathrm{r}$ & -0.479 & -0.410 & -0.347 \\
Left Axial Transverse & $\mathrm{p}$ & 0.002 & $<0.001$ & 0.020 \\
Left Coronal Craniocaudal & $\mathrm{r}$ & -0.540 & -0.482 & -0.439 \\
& $\mathrm{p}$ & $<0.001$ & $<0.001$ & 0.003 \\
Left Coronal Transverse & $\mathrm{r}$ & -0.156 & 0.044 & 0.097 \\
& $\mathrm{p}$ & 0.338 & 0.692 & 0.524 \\
Left Sagittal Anteroposterior & $\mathrm{r}$ & -0.531 & -0.467 & -0.429 \\
& $\mathrm{r}$ & $<0.001$ & $<0.001$ & 0.003 \\
Left Sagittal Craniocaudal & $\mathrm{p}$ & 0.196 & -0.162 & -0.171 \\
& $\mathrm{r}$ & 0.074 & 0.139 & 0.261 \\
Right Axial Anteroposterior & $\mathrm{p}$ & 0.651 & -0.021 & -0.070 \\
& $\mathrm{r}$ & -0.255 & 0.846 & 0.648 \\
Right Axial Transverse & $\mathrm{p}$ & 0.112 & -0.257 & -0.272 \\
& $\mathrm{r}$ & -0.593 & 0.018 & 0.070 \\
Right Coronal Craniocaudal & $\mathrm{p}$ & $<0.001$ & -0.386 & -0.203 \\
& $\mathrm{r}$ & -0.080 & $<0.001$ & 0.182 \\
Right Coronal Transverse & $\mathrm{p}$ & 0.626 & 0.015 & 0.042 \\
& $\mathrm{r}$ & -0.288 & 0.889 & 0.782 \\
Righ Sagittal Anteroposterior & $\mathrm{p}$ & 0.071 & -0.352 & -0.436 \\
& $\mathrm{r}$ & -0.445 & 0.001 & 0.003 \\
Right Sagittal Craniocaudal & $\mathrm{p}$ & 0.004 & -0.306 & -0.263 \\
& $\mathrm{r}$ & 0.116 & 0.004 & 0.081 \\
\hline Sper & $\mathrm{p}$ & 0.477 & 0.107 & 0.068 \\
& & & 0.330 & 0.656 \\
\hline
\end{tabular}

r: Spearman's correlation coefficient. 


\section{DISCUSSION}

In this study, we established the dimensions for nondiseased lacrimal glands as measured with MR images in a Turkish population sample and their associations with the side, age, and sex.

Previous studies have used CT or MR imaging to determine the size of the lacrimal gland located in the orbit (Gündüz et al.; Tamboli et al.; Harris et al.; Gao et al.). Although, the orbital bone structure and dimensions between the bony lacrimal fossa and lacrimal gland are easily visible with high-contrast resolution CT scans, it is difficult to evaluate the lacrimal gland itself with CT due to the softtissue density similarities between the lacrimal gland and the surrounding orbital structures (Gündüz et al.; Gao et al.). In order to overcome this difficulty, intravenous contrast was used; however, the results were inconsistent, leading to high interobserver variability (Gündüz et al.; Gao et al.). For lacrimal gland imaging, MR imaging has the benefits of the lack of ionizing radiation and high contrast resolution (Mafee \& Yang, 2006). Although MR imaging is associated with relatively long image acquisition times and a lower sensitivity for bone imaging, it is superior to CT in evaluating the soft-tissue structures. The anatomical detail of the images can be improved by fat suppression, which prevents high signal return from the orbital fat (Simon et al., 1988). The lacrimal gland has moderate and heterogeneous signal intensity on T1-weighted MR images, which can be enhanced with gadolinium (Hendrix et al., 1988; Hesselink \& Karampekios, 1996; Hughes \& Miszkiel, 2006). Although in the previous studies lacrimal gland dimensions were commonly measured by CT and MR imaging, no study has yet used the 3 Tesla MR unit for the assessment of the lacrimal gland. The 3 Tesla MR unit has the advantage of high field strength which makes scanning more comfortable and with less motion artifact (Tanenbaum, 2006). Therefore, MR imaging, particularly with fat suppression, is preferable for the assessment of the morphology of the lacrimal gland and its adjacent soft tissues (De Potter, 1995; Mafee \& Yang). We suggest that 3 Tesla MR unit would provide the optimal assessment of the lacrimal glands.

Although the lacrimal gland dimensions have been established in the coronal and axial planes (Tamboli et al.; Harris et al.), there have been no reports of the anteroposterior, craniocaudal, and transverse dimensions of the normal lacrimal gland as measured in the axial, coronal, and sagittal planes with MR imaging. As the dimensions in the coronal and axial planes reveal the anteroposterior and lateral depths of the lacrimal gland, sagittal plane scans can provide information about the height and depth of the lacri- mal gland temporal to the globe (De Potter; Mafee \& Yang). Therefore, in the present study, we evaluated the nonpathological lacrimal gland dimensions via MR imaging in the axial, coronal, and sagittal planes.

The average size of the left lacrimal gland was 13.0 $\mathrm{mm}$ and $5.0 \mathrm{~mm}$ in the anteroposterior and transverse dimensions of the axial plane, respectively, and $17.1 \mathrm{~mm}$ and $5.4 \mathrm{~mm}$ in the craniocaudal and transverse dimensions of the coronal plane, respectively. The average size of right lacrimal gland was larger in the anteroposterior and transverse dimensions of the axial plane (13.4 $\mathrm{mm}$ and 5.4 $\mathrm{mm}$, respectively), but smaller in the craniocaudal and transverse dimensions of the coronal plane $(16.5 \mathrm{~mm}$ and $5.2 \mathrm{~mm}$, respectively). Our measurements were compared with those of previous studies (Table IV), which showed that although the lacrimal gland size in our series was close to that of other reports, it exhibited dimensions specific to the study population.

Depending on the sex difference and asymmetry in the human body, various organs may show size differences, including the eyeball and orbit (Özer et al., 2016). In previous studies reporting the normal lacrimal gland dimensions as measured with ultrasound, CT, or MR imaging, controversial results were obtained for the gender and side differences in the size of the lacrimal gland (Avetisov et al., 2006; Tamboli et al.; Bingham et al., 2013; Lee et al., 2013). Bukhari et al. (2014) performed the first study to evaluate the lacrimal gland with MR imaging, and they reported that the lacrimal gland volume changed significantly in different ethnicities, that women have a higher lacrimal gland volume, and that the right gland volumes were larger than the left. They also found that the lacrimal gland volumes of 36 patients via CT and MR imaging yielded no significant differences. Forbes et al. (1985) also suggested that the lacrimal glands on the right side were larger when compared with the left side due to the larger orbital cavity on the right side, which includes muscles and fat. Moreover, Bingham et al. did not detect a significant difference in the lacrimal gland volume between male and female patients or between the right and left orbital cavities via CT. However, Tamboli et al. reported the normal dimensions of the lacrimal gland as measured via CT in the axial and coronal scans, and they only found a significant difference in the mean coronal length between the right and left orbits. The other dimensions were similar between the two sides, and there was no difference between the female and male patients. Lee et al. stated that there were no statistically significant differences in the lacrimal gland dimensions via CT between the sexes in a Korean population. They suggested that the axial and coronal widths of the lacrimal gland were slightly larger in the left orbit when compared with the right orbit. Danjem \& Salaam (2016) 
also demonstrated that there was no statistically significant difference between the sizes of the right and left lacrimal glands or between the male and female subjects for any dimension measured via brain $\mathrm{CT}$ in the healthy orbits of a Nigerian population. Bulbul et al. (2016) stated that the axial length, coronal length, and coronal width of the lacrimal gland via CT were comparable on the right and left sides, but the axial width showed a significant difference between the right and left orbits in a Turkish population. In our study while the axial transverse and sagittal craniocaudal dimensions of the lacrimal gland were significantly greater on the right side, the coronal craniocaudal and sagittal anteroposterior dimensions were greater on the left side. There were no statistically significant differences between the genders, except in the left coronal craniocaudal dimension of the lacrimal gland, which was significantly higher in the females than the males.

In the literature, most of the studies did not compare the right and left sides of the male and female subjects separately. However, in the present study, differences in the right-left sides were seen for both sexes in most of the dimensions. The right-left discrepancy in some of the parameters was different between sexes, indicating a pattern of lacrimal gland asymmetry showing differences between the male and female subjects.

In the human body, age-related changes are expected in many of the organs, including the lacrimal gland. In two histopathological autopsy studies, Obata and Obata et al. (1995), found positive correlations between the age and incidence of orbital lobe atrophy and fibrosis in women and periductal fibrosis in both men and women. Overall, the age alterations in the lacrimal gland structure begin in middle age in both humans and experimental animals. In humans, acinar atrophy and fibrosis start in younger patients, but increase with aging (Damato et al., 1984; Rocha et al., 2008). Therefore, several previous studies detected an inverse relationship between the lacrimal gland dimensions and the patient age in different ethnicities
(Forbes et al., 1985; Avetisov et al.; Tamboli et al.; Lee et al.; Özer et al.). The age of individuals was negatively correlated with the axial anteroposterior, axial transverse, and coronal transverse dimensions of the lacrimal gland on the left side, and the coronal transverse dimension on the right side. The right axial anteroposterior and right coronal transverse dimensions were negatively correlated with age in only the male subjects. Therefore, we suggest that the lacrimal gland volume decreases with age, while the effect of age on the lacrimal gland size may differ between the sexes.

The lacrimal gland dimensions in the three planes via MR imaging that were established in the present study can be helpful when distinguishing between normal and abnormal lacrimal glands. The proper evaluation of lacrimal gland imaging can identify an underlying pathology, avoid unnecessary referrals, and speed up the diagnosis and treatment of disease. Our results may implicate the importance of the national difference in the normal values of the lacrimal gland dimensions. In this study, we determined certain morphometric lacrimal gland parameters, which may be helpful in developing a database to determine the normal orbital values for the Turkish population so that a quantitative assessment of lacrimal gland diseases and deformities can be performed for both preoperative planning and postoperative follow-up. In addition, we presented a standard reference for interpreting lacrimal gland images obtained from orbital MR images, which may be useful in clinical trials that involve the lacrimal gland size. The TEM, rTEM, and R values showed an acceptable degree of intraobserver precision for all the measurements.

The limitations of this study should be addressed. First, it was limited by its retrospective design. Second, although care was taken to exclude all the patients with ocular diseases or symptoms, the presence of potential or unidentified lacrimal gland disorders, such as Sjogren's syndrome or sarcoidosis, cannot be ruled out. Finally, the

Table IV. The dimensions of lacrimal gland measured in the present study in comparison to those of previous studies.

\begin{tabular}{|c|c|c|c|c|c|c|c|c|}
\hline & \multicolumn{4}{|c|}{ Left lacrimal gland } & \multicolumn{4}{|c|}{ Right lacrimal gland } \\
\hline & $\begin{array}{l}\text { Axial } \\
\text { Antero- } \\
\text { posterior } \\
(\mathrm{mm})\end{array}$ & $\begin{array}{l}\text { Axial } \\
\text { Transver } \\
\text { se }(\mathrm{mm})\end{array}$ & $\begin{array}{l}\text { Coronal } \\
\text { Craniocaud } \\
\text { al }(\mathrm{mm})\end{array}$ & $\begin{array}{l}\text { Coronal } \\
\text { Transvers } \\
\text { e }(\mathrm{mm})\end{array}$ & $\begin{array}{l}\text { Axial } \\
\text { Antero- } \\
\text { posterior } \\
(\mathrm{mm})\end{array}$ & $\begin{array}{l}\text { Axial } \\
\text { Transverse } \\
(\mathrm{mm})\end{array}$ & $\begin{array}{l}\text { Coronal } \\
\text { Craniocaudal } \\
(\mathrm{mm})\end{array}$ & $\begin{array}{l}\text { Coronal } \\
\text { Transverse } \\
(\mathrm{mm})\end{array}$ \\
\hline Lee et al. & 14.7 & 4.3 & 20.7 & 3.8 & 14.9 & 4.1 & 20.9 & 3.6 \\
\hline Tamboli et al. & 14.5 & 4.8 & 16.9 & 5.2 & 14.7 & 5.1 & 17.7 & 5.2 \\
\hline Bulbul et al. & 16.0 & 4.0 & 18.3 & 4.1 & 16.2 & 4.1 & 18.3 & 4.1 \\
\hline Danjem etal. & 14.5 & 4.1 & 20.8 & 3.0 & 14.6 & 4.1 & 20.7 & 2.9 \\
\hline Current study & 13.0 & 5.0 & 17.1 & 5.4 & 13.4 & 5.4 & 16.4 & 5.2 \\
\hline
\end{tabular}


morphometric parameters of the lacrimal gland obtained in this study were limited to a sample of Turkish population, which cannot be generalized to all the Turkish population and other populations, thus further large-scale studies are needed.

In conclusion, this was the first study to determine certain morphometric parameters of the lacrimal gland by using 3 Tesla MR images in a Turkish population sample, which have clinical and experimental implications for the assessment of lacrimal gland pathologies. The lacrimal gland side, sex, and age of the individuals affect its dimensions. On the basis of the reference measurements in the present study, orbital 3 Tesla MR imaging can be used for the evaluation of the lacrimal gland and its pathologies.

GEDAR TOTUK, O. M.; KALKAY, A. B.; KABADAYI, K.; DEMIR. M. K. \& BARUT, C. Evaluación de las dimensiones de la glándula lagrimal con imágenes de RM en una muestra de población turca. Int. J. Morphol., 36(4):1431-1438, 2018.

RESUMEN: El objetivo de este estudio fue evaluar la morfología de la glándula lagrimal normal en tres ejes diferentes en una muestra de población turca, mediante el uso de imágenes de resonancia magnética $(\mathrm{RM})$ en relación con el sexo, la edad y lados izquierdos- derechos. Las imágenes RM obtenidas por RM 3 Tesla, en 85 individuos (40 mujeres y 45 hombres, edad media $42.20 \pm 23.30$ años, rango de edad entre 2 y 83 años) se realizaron en Göztepe Medical Park Hospital, entre diciembre de 2015 y julio de 2017. Considerando las enfermedades no orbitales, estas fueron evaluadas retrospectivamente. Se midieron las dimensiones anteroposterior, craneocaudal y transversal de la glándula lagrimal en los planos axial, coronal y sagital de las imágenes, y se evaluaron en relación con el lado, la edad y el sexo. Las dimensiones craneocaudal axiales transversales y sagitales de la glándula lagrimal fueron significativamente mayores en el lado derecho, y las dimensiones craneocaudal y anteroposterior sagital coronal fueron mayores en el lado izquierdo. Individuos femeninos y masculinos mostraron diferencias en términos de lados derecho-izquierdo en la mayoría de los parámetros. En el análisis de correlación de Spearman, la edad de los individuos se correlacionó negativamente con el anteroposterior axial izquierdo $(\mathrm{r}=-0.347, \mathrm{p}=0.020)$, transversal axial izquierdo $(\mathrm{r}=-0.439, \mathrm{p}=0.003)$, transversal coronal izquierdo $(\mathrm{r}=-0.429, \mathrm{p}=0.003)$, y las dimensiones transversales coronales derechas $(\mathrm{r}=-0.436, \mathrm{p}=0.003)$ de la glándula lagrimal. Este es el primer estudio que determina ciertos parámetros morfométricos de la glándula lagrimal en la muestra de la población turca. El lado de la glándula lagrimal, y el sexo y la edad de los individuos afectan sus dimensiones. En el presente estudio basado en las mediciones de referencia, la RM orbital se puede utilizar para la evaluación de la glándula lagrimal y sus patologías.

PALABRAS CLAVE: Imágenes de cabeza y cuello; Resonancia magnética; Dimensiones de la glándula lagrimal; Medición orbital.

\section{REFERENCES}

Avetisov, S. E.; Kharlap, S. I.; Markosian, A. G.; Safonova, T. N.; Likhvantseva, V. G. \& Nasnikova, I. Ultrasound spatial clinical analysis of the orbital part of the lacrimal gland in health. Vestnik Oftalmol., 122(6):14-6, 2006.

Bingham, C. M.; Castro, A.; Realini, T.; Nguyen, J.; Hogg, J. P. \& SivakCallcott, J. A. Calculated CT volumes of lacrimal glands in normal Caucasian orbits. Ophthalmic Plast. Reconstr. Surg., 29(3):157-9, 2013.

Bukhari, A. A.; Basheer, N. A. \& Joharjy, H. I. Age, gender, and interracial variability of normal lacrimal gland volume using MRI. Ophthalmic Plast. Reconstr. Surg., 30(5):388-91, 2014.

Bulbul, E.; Yazici, A.; Yanik, B.; Yazici, H. \& Demirpolat, G. Evaluation of lacrimal gland dimensions and volume in Turkish population with computed tomography. J. Clin. Diagn. Res., 10(2):TC06-8, 2016.

Damato, B. E.; Allan, D.; Murray, S. B. \& Lee, W. R. Senile atrophy of the human lacrimal gland: the contribution of chronic inflammatory disease. Br. J. Ophthalmol., 68(9):674-80, 1984.

Danjem, S. M. \& Salaam, A. J. Computed tomographic dimensions of the lacrimal gland in normal Nigerian orbits. Int. J. Sci. Res. Publ., 6(1):1515, 2016.

De Potter, P. MRI of the Eye and Orbit. Philadelphia, J. B. Lippincott, 1995.

Duke-Elder, S. \& Wybar, K. C. System of Ophthalmology. Vol. II. The Anatomy of the Visual System. London, Henry Kimpton, 1961.

Forbes, G.; Gehring, D. G.; Gorman, C. A.; Brennan, M. D. \& Jackson, I. T. Volume measurements of normal orbital structures by computed tomographic analysis. A. J. R. Am. J. Roentgenol., 145(1):149-54, 1985.

Gao, Y.; Moonis, G.; Cunnane, M. E. \& Eisenberg, R. L. Lacrimal gland masses. A. J. R. Am. J. Roentgenol., 201(3):W371-81, 2013.

Goto, R. \& Mascie-Taylor, C. G. Precision of measurement as a component of human variation. J. Physiol. Anthropol., 26(2):253-6, 2007.

Gündüz, K.; Shields, C. L.; Günalp, I. \& Shields, J. A. Magnetic resonance imaging of unilateral lacrimal gland lesions. Graefes Arch. Clin. Exp. Ophthalmol., 241(11):907-13, 2003.

Harris, M. A.; Realini, T.; Hogg, J. P. \& Sivak-Callcott, J. A. CT dimensions of the lacrimal gland in Graves orbitopathy. Ophthalmic Plast. Reconstr. Surg., 28(1):69-72, 2012.

Hendrix, L. E.; Massaro, B. M.; Daniels, D. L.; Smith, D. F. \& Haughton, V. M. Surface coil MR evaluation of a lacrimal gland carcinoma. $J$. Comput. Assist. Tomogr., 12(5):866-8, 1988.

Hesselink, J. R. \& Karampekios, S. Normal computed tomography and magnetic resonance imaging anatomy of the globe, orbit, and visual pathways. Neuroimaging Clin. N. Am., 6(1):15-27, 1996.

Hughes, G. K. \& Miszkiel, K. A. Imaging of the lacrimal gland. Semin. Ultrasound CT MR, 27(6):476-91, 2006.

Jung, W. S.; Ahn, K. J.; Park, M. R.; Kim, J. Y.; Choi, J. J.; Kim, B. S. \& Hanh, S. T. The radiological spectrum of orbital pathologies that involve the lacrimal gland and the lacrimal fossa. Korean J. Radiol., 8(4):33642, 2007.

Kemper, C. J. \& Schwerdtfeger, A. Comparing indirect methods of digit ratio (2D:4D) measurement. Am. J. Hum. Biol., 21(2):188-91, 2009.

Lee, J. S.; Lee, H.; Kim, J. W.; Chang, M.; Park, M. \& Baek, S. Computed tomographic dimensions of the lacrimal gland in healthy orbits. $J$. Craniofac. Surg., 24(3):712-5, 2013.

Mafee, M. F. \& Yang, G. Clinical Magnetic Resonance Imaging. Philadelphia, W. B. Saunders, 2006.

Obata, H. Anatomy and histopathology of the human lacrimal gland. Cornea, 25(10 Suppl. 1):S82-9, 2006.

Obata, H.; Yamamoto, S.; Horiuchi, H. \& Machinami, R. Histopathologic study of human lacrimal gland. Statistical analysis with special reference to aging. Ophthalmology, 102(4):678-86, 1995.

Özer, C. M.; Öz, I. I.; Serifoglu, I.; Büyükuysal, M. Ç. \& Barut, Ç. Evaluation of eyeball and orbit in relation to gender and age. $J$. Craniofac. Surg., 27(8):e793-e800, 2016. 
GEDAR TOTUK, O. M.; KALKAY, A. B.; KABADAYI, K.; DEMIR. M. K. \& BARUT, C. Evaluation of lacrimal gland dimensions with MR imaging in a Turkish population sample. Int. J. Morphol., 36(4):1431-1438, 2018.

Rocha, E. M.; Alves, M.; Rios, J. D. \& Dartt, D. A. The aging lacrimal gland: changes in structure and function. Ocul. Surf., 6(4):162-74, 2008.

Shields, C. L.; Shields, J. A.; Eagle, R. C. \& Rathmell, J. P. Clinicopathologic review of 142 cases of lacrimal gland lesions. Ophthalmology, 96(4):431-5, 1989.

Simon, J.; Szumowski, J.; Totterman, S.; Kido, D.; Ekholm, S.; Wicks, A. \& Plewes, D. Fat-suppression MR imaging of the orbit. A. J. N. R. Am. J. Neuroradiol., 9(5):961-8, 1988.

Tamboli, D. A.; Harris, M. A.; Hogg, J. P.; Realini, T. \& Sivak-Callcott, J. A. Computed tomography dimensions of the lacrimal gland in normal Caucasian orbits. Ophthalmic Plast. Reconstr. Surg., 27(6):453-6, 2011.

Tanenbaum, L. N. Clinical 3T MR imaging: mastering the challenges. Magn. Reson. Imaging Clin. N. Am., 14(1):1-15, 2006.

Ulijaszek, S. J. \& Mascie-Taylor, C. N. (Eds.). Intra- and Inter-Observer Error in Anthropometric Measurement. Cambridge, Cambridge University Press, 1994. pp.165-77.

Weinberg, S. M.; Scott, N. M.; Neiswanger, K. \& Marazita, M. L. Intraobserver error associated with measurements of the hand. Am. J. Hum. Biol., 17(3):368-71, 2005.
Corresponding author:

Dr. Ozgun Melike Gedar Totuk

Bahcesehir University Faculty of Medicine

Department of Ophthalmology

Yenisahra Mah. Batman Sok

No:66-68 Sahrayicedit

Kadikoy

Istanbul

TURKEY

E-mail: melikegedar@gmail.com

Received: 05-06-2018

Accepted: 21-08-2018 